

\title{
Binding strategies for capturing and growing Escherichia coli on surfaces of biosensing devices
}

Sébastien Choinière, Eric Frost, Jan Dubowski

\section{To cite this version:}

Sébastien Choinière, Eric Frost, Jan Dubowski. Binding strategies for capturing and growing Escherichia coli on surfaces of biosensing devices. Talanta, 2019, 192, pp.270-277. 10.1016/j.talanta.2018.09.043 . hal-01891709

\section{HAL Id: hal-01891709 \\ https://hal.science/hal-01891709}

Submitted on 8 Nov 2018

HAL is a multi-disciplinary open access archive for the deposit and dissemination of scientific research documents, whether they are published or not. The documents may come from teaching and research institutions in France or abroad, or from public or private research centers.
L'archive ouverte pluridisciplinaire HAL, est destinée au dépôt et à la diffusion de documents scientifiques de niveau recherche, publiés ou non, émanant des établissements d'enseignement et de recherche français ou étrangers, des laboratoires publics ou privés. 


\title{
Binding strategies for capturing and growing Escherichia coli on surfaces of biosensing devices
}

\author{
Sébastien Choinière ${ }^{\mathrm{a}, \mathrm{b}}$, Eric H. Frost ${ }^{\mathrm{a}, \mathrm{b}}$, Jan J. Dubowski ${ }^{\mathrm{a}^{*}}$
}

anterdisciplinary Institute for Technological Innovation (3IT), Laboratory for Quantum Semiconductors and Photon-based BioNanotechnology, CNRS UMI-3463, Université de Sherbrooke, 3000, boul. de l'Université, Sherbrooke, Québec, Canada, J1K 0A5

${ }^{b}$ Department of Microbiology and Infectiology, Centre de Recherche du CHUS, Faculty of Medicine and Health Sciences, Université de Sherbrooke, 3001, 12th Avenue North Sherbrooke, Québec, Canada, J1H 5N4

jan.j.dubowski@usherbrooke.ca

URL: http://www.dubowski.ca

*Corresponding author. Jan J. Dubowski, Interdisciplinary Institute for Technological Innovation (3IT), Laboratory for Quantum Semiconductors and Photon-based 
BioNanotechnology, Université de Sherbrooke, 3000, boul. de l'Université, Sherbrooke,

Québec, Canada, J1K 0A5; Tel.: +1 819-821-8000 ext. 62528; fax: +1 819-821-7937

\begin{abstract}
Antibiotic resistant bacteria have become a threat to world health. An advanced method of detection, based on the matrix assisted laser desorption ionisation time-of-flight mass spectroscopy can identify bacteria relatively rapidly, but it is not suitable to measure bacterial antibiotic resistance. Biosensors may be able to detect resistance by monitoring growth after capture on sensor surfaces but this option has not been addressed adequately. We have evaluated the growth of Escherichia coli after capture in 96 well microplates and observed that growth/capture efficiency was relatively similar for antibody-based techniques, but non-specific capture varied considerably. We confirm that neutravidin binds $E$. coli non-specifically, which limited its use with biotinylated antibodies or aptamers. Centrifugation enhanced bacterial growth/capture considerably, indicating that procedures enhancing the interaction between bacteria and surface-bound antibody have the potential to improve growth efficiency. Capture and growth required larger numbers of bacteria than capture and detection on biosensor surfaces. Previously, we reported that the minimum concentration of live $E$. coli required for initiating growth on a GaAs/AlGaAs biosensor was $\sim 10^{5} \mathrm{CFU} / \mathrm{mL}$ [Nazemi et al., Talanta 178 (2018) 69-77], and we speculated that this could be related to the poisonous effect of Ga- and As-ions released during dark corrosion of the biosensor, however in the present report we observed that the same minimum concentration of E. coli was required for growth in an ELISA plate. Thus, we argue that this limitation was related rather to bacterial inhibition by the capture antibodies. Indeed, antibodies at titres designed to capture bacteria inhibited bacterial growth when the bacteria were added to growth medium at titres less than $10^{5} \mathrm{CFU} / \mathrm{mL}$, indicating that antibodies may be responsible for the higher limits of sensitivity due to their potential to restrict bacterial growth. However, we did not observe E. coli release after $6 \mathrm{~h}$ following the capture indicating that these bacteria did not degrade antibodies.
\end{abstract}

Keywords: Biosensor, Bacteria detection, Bacterial growth, Escherichia coli, Antibiotic resistance, Surface capture, Antibody 


\section{Introduction}

The rise in multi-resistant microorganisms represents a major threat for public health worldwide [1-3]. Microorganisms also cause problems for water, food, and pharmaceutical industries [3-6]. Current methods of microbial detection, like culture and detection in an automated instrument, polymerase chain reaction (PCR) and immunology-based methods such as enzyme-linked immunosorbent assays (ELISA), are time consuming (24-48 h), complex, require trained personnel and may require enrichment steps to detect low concentrations [7,8]. Matrix assisted laser desorption ionization time of flight mass spectrometry (MALDI-TOF MS) has emerged as a promising method for rapid, sensitive and cost-effective bacterial identification, but provides only limited determination of antibiotic resistance $[9,10]$. Even though these techniques are reliable, the recent increase in antibiotic resistance of bacteria $[1-3,11,12]$ has pushed health organizations to request alternative, fast, specific and sensitive methods for detection, identification and determination of antibiotic resistance of bacteria [13]. Biosensors [14] have been increasing in popularity as an alternative method due to their simplicity, speed, sensitivity, real-time monitoring, portability of the device and, potentially, low cost of testing [7,8]. Among numerous types of biosensors, the most frequently investigated appear to be those based on optical [15-17] and electrochemical $[7,8]$ methods. Surface plasmon resonance (SPR)-based and electrochemical impedancebased sensors using gold $(\mathrm{Au})$ surfaces have shown attractive sensitivity for bacterial detection [7,15], but have rarely been used to measure antibiotic sensitivity [18]. Photoluminescence-based biosensors that usually employ GaAs surfaces have been used 
for detection of some bacteria [19-24] allowing quantification down to $10^{3}$ colony forming units of bacteria (CFU) per $\mathrm{ml}$ and even lower with chemotaxis [25].

Photoluminescence-based biosensors have also been employed to determine antibiotic resistance of E. coli, but only with relatively low limits of detection [24]. The response of these biosensors depends on the efficiency of capturing target biomolecules with targetspecific ligands [26], such as antibodies [8,17], aptamers [27], antimicrobial peptides [28], lectins [15], phages [16] or molecular imprints [29] as opposed to non-specific binding to Au surface after coating with poly-lysine [18].

The present study focuses on determining the best capture efficiency that can be employed on a biosensor surface and understanding why capture and growth is so much less efficient than capture and detection. The subsequent growth of the captured bacteria is an important factor to consider in order to monitor bacterial growth for antibiotic sensitivity tests in further studies. Typically, Au-based surfaces have been employed by numerous biosensors, although a large variety of biosensors employ $\mathrm{GaAs}, \mathrm{Si}$, and oxide coated surfaces. The purpose of this work was to investigate different bacterial capture strategies while working with plastic surfaces of 96 well plates, which allowed testing different binding structures in a short period of time. To this end, we have investigated passively adsorbed goat and chicken antibodies that are the recognized reference method for antigen capture on ELISA plates [30]. We have compared them with strategies more amenable to GaAs or Au surfaces such as goat antibodies covalently linked to a plate with a carboxyl group and biotinylated goat antibodies or biotinylated aptamers linked via passively adsorbed neutravidin. Since low numbers of bacteria would not grow after capture, we employed high concentrations of bacteria as would be found in suspended 
bacterial colonies to be identified by MALDI-TOF. Although centrifugation is more challenging to input in a fully automated portable device, it can be considered as a strategy to investigate enhanced surface capture [31], e.g., as a proxy for other strategies such as chemotaxis or electrophoresis that might possibly overcome electrostatic repulsion between bacteria and surfaces. Centrifugation at less than $5000 \mathrm{G}$ was not expected to disrupt surface integrity of bacteria [32] and it is easy to integrate into 96 well protocols. By growing bacteria captured by antibodies, we have investigated the ability of bacteria to degrade the antibodies and release themselves from capture.

\section{Materials and Methods}

\subsection{Materials and reagents}

Tests were carried out with clear Corning 96 well plates 3590 (ELISA plate) from Fischer Scientific (Whitby, ON, CAN), and clear carboxylated 96 well plates (COOH plate) from BioWorld (Dublin, OH, USA). Common laboratory chemicals including $\mathrm{NaH}_{2} \mathrm{PO}_{4}$, $\mathrm{Na}_{2} \mathrm{HPO}_{4}, \mathrm{NaCl}, \mathrm{NaHCO}_{3}, \mathrm{Na}_{2} \mathrm{CO}_{3}$, polyoxyethylene sorbitan monolaurate (Tween-20), and $\mathrm{MgCl}_{2}$ were from Fisher Scientific (Fair Lawn, NJ, USA). Bovine serum albumin (BSA) was from Roche Diagnostics (Indianapolis, IN, USA), ethylenediaminetetraacetic acid disodium salt dihydrate (EDTA), 1-ethyl-3-(3-diméthylaminopropyl)carbodiimide (EDC) and N-hydroxysuccinimide (NHS) were from Sigma-Aldrich (St. Louis, MO, USA) or alternatively, EDC and NHS were from Biacore (GE Healthcare bio-science AB, Uppsala, Sweden). The purified IgG fraction of goat antibodies (Ab) directed against $E$. coli, both biotinylated and non-biotinylated, were from ViroStat (Portland, ME, USA), 
chicken Ab directed against E. coli from Immune Biosolutions (Sherbrooke, QC, CAN), biotinylated aptamers (Apt) (E2, EcO3R and EcO4R) [33,34] were synthesized by Integrated DNA Technologies (IDT) (Coralville, IA, USA), neutravidin (NA), Salmon sperm DNA and Tris-HCl were from Invitrogen (Burlington, ON, CAN). Tryptone, nutrient broth (NB) and agar were from Becton, Dickinson and Company (BD) (Mississauga, ON, CAN) and glucose from J. T. Baker (Phillipsburg, NJ, USA).

A genetically modified strain of $E$. coli K12 BW25113 continually expressing the green fluorescent protein (GFP) was provided by Sébastien Rodrigue from the Département de Biologie of the Université de Sherbrooke, and referred to as E. coli GFP. The E. coli GFP was conserved at $4{ }^{\circ} \mathrm{C}$ on nutrient agar $(\mathrm{NB}+15 \%$ agar) medium and refreshed each month. A fresh culture of E. coli GFP was used each day of tests, after incubation overnight $(\mathrm{O} / \mathrm{N})$ at $37{ }^{\circ} \mathrm{C}$ in $\mathrm{NB}$ medium. Tryptone glucose $(1 \%$ tryptone, $1 \%$ glucose and $0.5 \% \mathrm{NaCl})(\mathrm{TG})$ was used for the capture tests to allow subsequent growth and reduce the fluorescent background compared with NB or Luria-Bertani medium. Fluorescence was measured using a CytoFluor Series 4000 (Applied Biosystems, Foster City, CA, USA) microplate reader with excitation at $485 \mathrm{~nm}$ and emission at $535 \mathrm{~nm}$. Data were exported to Microsoft Excel and GraphPad Prism version 7.03 for Windows (GraphPad Software, La Jolla, California, USA, www.graphpad.com) for further analysis.

\subsection{Standard curve for quantification of E. coli GFP}

In order to quantify captured $E$. coli GFP, a standard curve was made with unbound $E$. coli GFP using $200 \mu \mathrm{L}$ of known concentrations of $E$. coli GFP suspended in TG medium 
in a 96 well plate without $\mathrm{Ab}$. Concentrations of $10^{1.2}, 10^{2.2}, 10^{3.2}, 10^{4.2}, 10^{5.2}$ and $10^{6.2}$ colony forming units per $\mathrm{mL}(\mathrm{CFU} / \mathrm{mL})$ were monitored for $12 \mathrm{~h}$ with data taken each 15 or $30 \mathrm{~min}$ in the CytoFluor. Data points for each growth curve were plotted to identify the time when fluorescence increased above background levels, which was called the Time threshold (Tt).

\subsection{Passive capture of antibodies.}

For the capture of bacteria with $\mathrm{Ab}, 100 \mu \mathrm{L}$ of goat or chicken $\mathrm{Ab}$ (concentrations tested included: $0 ; 0.5 ; 1 ; 2 ; 5 ; 10 ; 20 ; 50 ; 100$ and $200 \mu \mathrm{g} / \mathrm{mL}$ ) in carbonate buffer $\mathrm{pH} 9.6$ were added to the wells of a 96 well plate and incubated $\mathrm{O} / \mathrm{N}$ at $4{ }^{\circ} \mathrm{C}$ with agitation. The wells were washed 5 times with $300 \mu \mathrm{L}$ of PBS $+0.05 \%$ Tween-20 (PBST) and $200 \mu \mathrm{L}$ of blocking solution (PBST $+3 \%$ BSA) were added to the wells and incubated $\mathrm{O} / \mathrm{N}$ at $4{ }^{\circ} \mathrm{C}$ with agitation.

\subsection{Active capture of goat Ab with EDC/NHS}

To test similar structures to those used with Au or GaAs surfaces functionalized with carboxyl-thiol linkers [35], $\mathrm{COOH}$ plates were used with activators EDC/NHS to covalently link the carboxyl group of the wells with an amine group from the Ab. For this structure, $50 \mu \mathrm{L}$ of fresh solutions of $800 \mathrm{mM}$ EDC in water and $200 \mathrm{mM}$ NHS in water were used to activate the carboxyl group in the wells for $1 \mathrm{~h}$ at room temperature (RT). The EDC/NHS from Sigma-Aldrich and EDC/NHS from Biacore were tested separately for comparison. After washing the wells, $100 \mu \mathrm{L}$ of $\mathrm{Ab}$ (concentrations tested: $0 ; 20 ; 100$ 
and $200 \mu \mathrm{g} / \mathrm{mL}$ ) in water were added and then incubated for $1 \mathrm{~h}$ at RT. The wells were washed between each step with PBST and blocked as mentioned above.

\subsection{Capture of biotinylated antibodies or aptamers with neutravidin bound to surfaces}

In order to simulate capture of biotinylated linkers to $\mathrm{Au}$ or $\mathrm{GaAs}$ surfaces (functionalized with biotin alkane thiols and NA) [20], we bound NA directly to 96 well plates. $100 \mu \mathrm{L}$ of NA in PBS (concentrations tested: $0 ; 0.1 ; 0.2 ; 0.3 ; 0.4 ; 0.5 ; 0.6 ; 0.7$; $0.8 ; 0.9 ; 1 ; 2 ; 3 ; 4 ; 5 ; 10 ; 20 ; 50 ; 100$ and $200 \mu \mathrm{g} / \mathrm{mL}$ ) was added to the wells and incubated $\mathrm{O} / \mathrm{N}$ at $4{ }^{\circ} \mathrm{C}$ with agitation. The wells were washed and, for the antibody before bacteria $(\mathrm{AB})$ method, $100 \mu \mathrm{L}$ of biotinylated $\mathrm{Ab}$ (concentrations tested: $0 ; 20 ; 100$ and $200 \mu \mathrm{g} / \mathrm{mL}$ ) in PBS or $100 \mu \mathrm{L}$ of biotinylated aptamer in their respective binding buffers (BB) (BB E2: PBST + $1 \%$ BSA $+0.1 \mathrm{mg} / \mathrm{mL}$ salmon sperm DNA, BB EcO3R and EcO4R: 10 mM Tris- $\mathrm{HCl} \mathrm{pH} 7.5+0.5 \mathrm{M} \mathrm{NaCl}+1 \mathrm{mM} \mathrm{MgCl} 2)[32,33]$ were added to the wells and incubated $1 \mathrm{~h}$ at $37^{\circ} \mathrm{C}$ with agitation. The washing and blocking steps were done as mentioned above.

Alternatively, in the pre-incubation (PI) method, biotinylated Ab or Apt were preincubated with $100 \mu \mathrm{L}$ of $10^{8} \mathrm{CFU} / \mathrm{mL}$ of $E$. coli GFP in PBS or in the specific BB of each Apt in micro centrifuge tubes and incubated $1 \mathrm{~h}$ at $37^{\circ} \mathrm{C}$ with agitation. The tubes were centrifuged $15 \mathrm{~min}$ at $2900 \mathrm{G}$ and the supernatant was removed and the pellet washed with $100 \mu \mathrm{L}$ of PBS or with the respective BB of each Apt. The content of the tubes was then transferred to the wells of the NA-coated plate and incubated $1 \mathrm{~h}$ at $37^{\circ} \mathrm{C}$ 
with agitation. The blocking step was done as mentioned above and the steps of monitoring and analysis were performed as described below.

\subsection{Capture of E. coli GFP with ligands bound to 96 well plates}

After the blocking step, the wells were washed 5 times with PBST, then $200 \mu \mathrm{L}$ of $E$. coli GFP (usually at $10^{8} \mathrm{CFU} / \mathrm{mL}$, unless otherwise mentioned) in PBS was added to the wells and incubated $1 \mathrm{~h}$ at $37^{\circ} \mathrm{C}$ with agitation. The wells were washed 5 times with 300 $\mu \mathrm{L}$ of PBST including $100 \mathrm{mM}$ EDTA prior to addition of $200 \mu \mathrm{L}$ of TG medium to the wells. The plate was incubated in a CytoFluor microplate reader for $12 \mathrm{~h}$ at $37^{\circ} \mathrm{C}$ with fluorescence intensity measured $\left(\lambda_{\mathrm{abs}}=485 \mathrm{~nm}, \lambda_{\mathrm{em}}=535 \mathrm{~nm}\right)$ every 15 or $30 \mathrm{~min}$. A quantification curve with unbound $E$. coli GFP was constructed in parallel with each capture test. The quantity of bacteria captured was estimated by comparison with the parallel standard curve.

\subsection{Centrifugation}

Using the protocol described for passively adsorbed goat $\mathrm{Ab}$, different concentrations of bacteria $\left(10^{0.2}, 10^{1.2}, 10^{2.2}, 10^{3.2}, 10^{4.2}, 10^{5.2}, 10^{6.2}, 10^{7.2}\right.$ and $10^{8.2}$ bacteria/mL) were added to the wells after the $\mathrm{Ab}$ adsorption and blocking steps. The plates were centrifuged $5 \mathrm{~min}$ at $250 \mathrm{G}$ or $10 \mathrm{~min}$ at $550 \mathrm{G}$ to pellet the bacteria gently [36] followed by incubation for $1 \mathrm{~h}$ at $37{ }^{\circ} \mathrm{C}$ to allow the $\mathrm{Ab}$ bound to the plate to capture the bacteria. The plates were then washed with PBST + $100 \mathrm{mM}$ EDTA and incubated in the fluorometer as described above. 


\subsection{Antibody inhibition of bacterial growth}

In order to titrate $\mathrm{Ab}$ inhibition of $E$. coli GFP growth, $100 \mu \mathrm{L}$ of goat anti-E. coli $\mathrm{Ab}$ at concentrations of $0.5 ; 1 ; 2 ; 5 ; 10 ; 20 ; 50$ and $100 \mu \mathrm{g} / \mathrm{mL}$ in TG and $100 \mu \mathrm{L}$ of $E$. coli

GFP (concentrations tested: $10^{0.5}, 10^{1.5}, 10^{2.5}, 10^{3.5}, 10^{4.5}, 10^{5.5}$ and $10^{6.5} \mathrm{CFU} / \mathrm{mL}$ ) in TG were added to wells of a 96 well plate. The plate was incubated in the fluorometer with data taken every $15 \mathrm{~min}$ as above.

\subsection{E. coli GFP degradation of captured antibodies}

In order to ascertain if $E$. coli GFP could degrade Ab in the well after capture, we have investigated the growth of bacteria at $37^{\circ} \mathrm{C}$ in $\mathrm{TG}$ medium in uncoated and $\mathrm{Ab}$ functionalized wells. The number of bacteria was determined after washing designed to remove Ab released bacteria. E. coli GFP was captured on plates prepared with passively adsorbed goat $\mathrm{Ab}$ and unbound bacteria washed off as described above leaving attached bacteria in the well with $200 \mu \mathrm{L}$ of TG. The plate was incubated in the fluorometer. After 0 to $6 \mathrm{~h}$, some wells of the plate were washed with PBST $+100 \mathrm{mM}$ EDTA and $200 \mu \mathrm{L}$ of TG was added to the washed wells to quantify the bacteria still bound, and investigate if bacteria were still retained by the $\mathrm{Ab}$ or if the bacteria had degraded the $\mathrm{Ab}$ and been removed by the washing step.

\section{Results}




\subsection{Quantification of E. coli GFP}

Growth curves for $E$. coli GFP synthesis were analyzed to determine the time when fluorescence increased above background levels ( $\mathrm{Tt}$ ), either by identifying the abscissa crossing point of the tangent of the ascending portion of the curves between $25 \%$ and 75\% of maximal fluorescence [37], as shown in Fig. 1a, or using the maximum of the second derivative of the growth curve [38], as shown in Fig. 1b. Standard plots of Tt versus bacterial concentration were constructed for both of these methods as shown in Fig. 1c. Initial concentrations of bacteria could be estimated from these plots by measuring the $\mathrm{Tt}$ of unknown samples. 




(a)

(b)

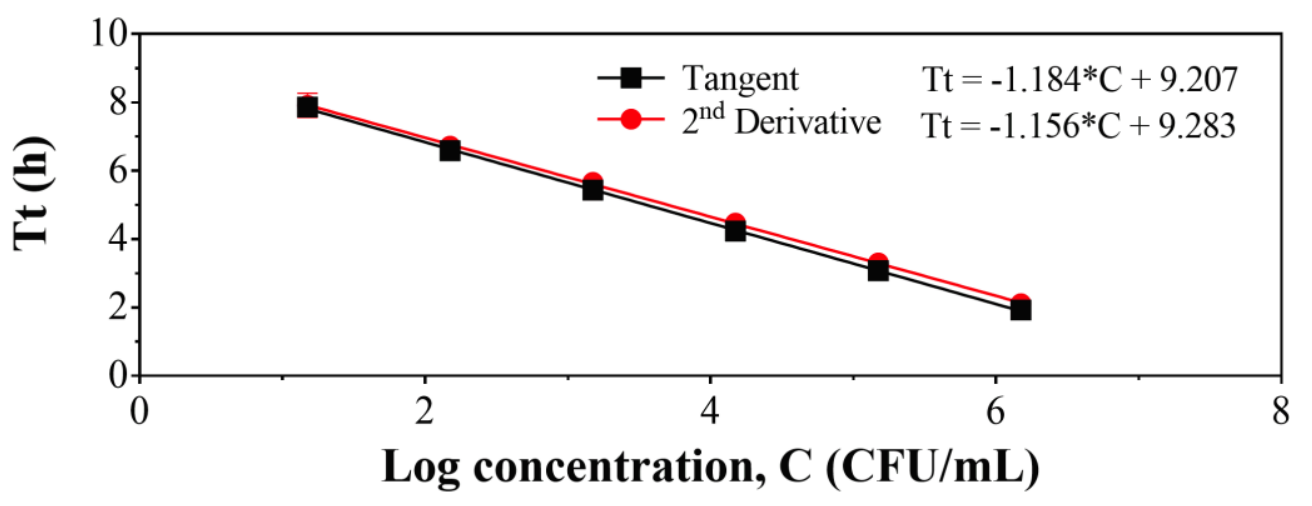

(c)

Fig. 1: Time dependent fluorescence intensity from different bacterial dilutions grown in TG in microtitre plate wells (a). Tangents of the ascending portion of the curves between $25 \%$ and $75 \%$ of maximal fluorescence were drawn to allow estimation of $\mathrm{Tt}$ from the 
intersection with the abscissa. Maxima of $2^{\text {nd }}$ derivatives of the plots in Fig. 1a also allow $\mathrm{Tt}$ values to be estimated (b). Dependence of $\mathrm{Tt}$ on bacterial concentration (c).

\subsection{Capture of E. coli with passively bound antibodies}

As a standard reference binding interface, Ab were adsorbed to 96 well ELISA plates.

The results, summarized in Table 1, indicate that E. coli GFP bacteria were captured with passively adsorbed goat $\mathrm{Ab}$ at $10^{4.3} \mathrm{CFU} / \mathrm{mL}$ when $10^{8} \mathrm{CFU} / \mathrm{mL}$ of these bacteria in PBS were added to wells. When chicken $\mathrm{Ab}$ were passively adsorbed, a comparable concentration of $E$. coli GFP at $10^{4.0} \mathrm{CFU} / \mathrm{mL}$ was captured. In the absence of $\mathrm{Ab}, E$. coli GFP were non-specifically captured by the structure up to $10^{0.2} \mathrm{CFU} / \mathrm{mL}$.

Table 1: Summary of capture methods

\begin{tabular}{|c|c|c|c|c|c|}
\hline & $\begin{array}{c}\text { Specific } \\
\text { (ligand-based) }\end{array}$ & $\begin{array}{l}\text { Non-specific } \\
\text { (no ligand) }\end{array}$ & Snecific - Non & & \\
\hline Method & $\begin{array}{c}\log \mathrm{C}_{\mathrm{sp}} \\
(\mathrm{CFU} / \mathrm{mL})\end{array}$ & $\begin{array}{c}\log \mathrm{C}_{\mathrm{nsp}} \\
(\mathrm{CFU} / \mathrm{mL})\end{array}$ & $\begin{array}{c}\text { specific } \\
\log \left(\mathrm{C}_{\text {sp }} / \mathrm{C}_{\text {nsp }}\right)\end{array}$ & $\begin{array}{c}\text { [NA] } \\
(\mu \mathrm{g} / \mathbf{m L})\end{array}$ & [Ligand] \\
\hline $\begin{array}{l}\text { Passive Goat } \\
\mathrm{Ab}\end{array}$ & $4.3 \pm 0.8$ & $0.1 \pm 0.1$ & 4.2 & - & $\begin{array}{c}200 \\
\mu \mathrm{g} / \mathrm{mL} \\
\mathrm{Ab}\end{array}$ \\
\hline $\begin{array}{c}\text { Passive } \\
\text { Chicken Ab }\end{array}$ & 4.0 & $0.2 \pm 0.4$ & 3.8 & - & unknown \\
\hline Covalent & $3.5 \pm 1.4$ & $0.0 \pm 0.2$ & 3.5 & - & 200 \\
\hline
\end{tabular}


Covalent

Sigma

$$
3.7 \pm 1.1 \quad 2.2 \pm 1.9
$$

1.5

$\mu \mathrm{g} / \mathrm{mL}$

NA-Antibody

$\begin{array}{lllll}4.9 \pm 0.6 & 2.3 \pm 0.7 & 2.6 & 1 & \mu \mathrm{g} / \mathrm{mL}\end{array}$

PI

$\mathrm{Ab}$

NA-Antibody

$$
4.0 \pm 0.6 \quad 2.8 \pm 0.8
$$

1.2

$50 \mu \mathrm{g} / \mathrm{mL}$

$\mathrm{AB}$

NA-Aptamer

$$
5.2 \pm 0.7 \quad 3.3 \pm 1.2
$$

1.9

E2 500

PI

NA-

$$
3.7 \pm 0.7
$$

$3.3 \pm 1.2$

0.4

100

AptamerAB

Passive Goat $\mathrm{Ab}=$ Reference method by using passively adsorbed goat $\mathrm{Ab}$

Passive Chicken $\mathrm{Ab}=$ Method using passively adsorbed chicken $\mathrm{Ab}$

Covalent Biacore $=$ Method using $\mathrm{COOH}$-plate and EDC/NHS from Biacore with goat $\mathrm{Ab}$

Covalent Sigma $=$ Method using COOH-plate and EDC/NHS from Sigma with goat Ab NA-Antibody PI = Pre-incubation Method using passively adsorbed NA and biotinylated goat $\mathrm{Ab}$ 
NA-Antibody $\mathrm{AB}=$ Antibodies before bacteria Method using passively adsorbed NA and biotinylated goat $\mathrm{Ab}$

NA-Aptamer PI $=$ Pre-incubation Method using passively adsorbed NA and biotinylated Apt

NA-Aptamer AB = Antibodies before bacteria Method using passively adsorbed NA and biotinylated Apt 


\subsection{Capture of E. coli with covalently bound goat $\operatorname{Ig} G$ antibodies}

$\mathrm{Ab}$ were linked with a $\mathrm{COOH}$ plate that had been activated with EDC/NHS to covalently link an amine group of the Ab. With EDC/NHS from Biacore, E. coli GFP were captured at $10^{3.5} \mathrm{CFU} / \mathrm{mL}$ with goat $\mathrm{Ab}$. With EDC/NHS from Sigma-Aldrich a comparable ligand-based binding was achieved at $10^{3.7} \mathrm{CFU} / \mathrm{mL}$, but this was also associated with a considerably more non-specific capture of bacteria at $10^{2.2} \mathrm{CFU} / \mathrm{mL}$ compared to EDC/NHS from Biacore giving $10^{\circ} \mathrm{CFU} / \mathrm{mL}$ (Table 1). The number of bacteria captured by the covalently bound $\mathrm{Ab}$ increased over 10 -fold for the 4 -fold increased concentration of Ab solutions (from 5 to $200 \mu \mathrm{g} / \mathrm{mL}$ ), which is comparable to the increased number of bacteria captured on passively bound $\mathrm{Ab}$ for the same increase of the concentration of Abs (Table 2).

Table 2: Capture of bacteria by different amounts of passively adsorbed or covalentlybound antibodies.

\begin{tabular}{ccc}
\hline $\begin{array}{c}\text { Ab conc. } \\
(\mu \mathrm{g} / \mathrm{mL})\end{array}$ & $\begin{array}{c}\text { Passively adsorbed } \mathrm{Ab} \\
\log \mathrm{C}(\mathrm{CFU} / \mathrm{mL})\end{array}$ & $\begin{array}{c}\text { Covalently bound } \mathrm{Ab} \\
\log \mathrm{C}(\mathrm{CFU} / \mathrm{mL})\end{array}$ \\
\hline 200 & $3.9 \pm 0.3$ & $3.7 \pm 1.1$ \\
100 & $3.8 \pm 0.3$ & $3.5 \pm 1.2$ \\
50 & $3.7 \pm 0.3$ & $3.2 \pm 1.3$ \\
\hline
\end{tabular}




\begin{tabular}{lll}
\hline 20 & $3.4 \pm 0.4$ & $2.9 \pm 1.3$ \\
10 & $3.4 \pm 0.5$ & $2.8 \pm 1.4$ \\
5 & $3.0 \pm 0.4$ & $2.6 \pm 1.4$ \\
1 & $1.6 \pm 0.5$ & $2.0 \pm 1.3$ \\
0.5 & $2.4 \pm 2.0$ \\
0 & $0.3 \pm 0.5$ & $2.2 \pm 1.9$ \\
& \\
\hline * Different concentrations of Ab were passively adsorbed or covalently bound to surfaces. \\
Capture of $E$. coli was with PBST for the Passively Adsorbed Ab method and with PBS \\
for the Covalently-Bound AB method. Sigma EDC/NHS was used for the Covalently- \\
Bound AB method. \\
* Different concentrations of Ab were passively adsorbed or covalently bound to surfaces. \\
Capture of $E$. coli was with PBST for the Passively Adsorbed Ab method and with PBS \\
for the Covalently-Bound AB method. Sigma EDC/NHS was used for the Covalently- \\
Bound AB method.
\end{tabular}

Bound AB method.

\subsection{Capture of E. coli with biotinylated antibodies and neutravidin}

Neutravidin was bound passively to an ELISA plate, then biotinylated Ab followed by bacteria ( $\mathrm{AB}$ method) or bacteria preincubated with biotinylated $\mathrm{Ab}$ (PI method) were added. More efficient bacterial capture was observed with the PI method than with the $\mathrm{AB}$ method $\left(10^{4.9} \mathrm{CFU} / \mathrm{mL}\right.$ versus $\left.10^{4.0} \mathrm{CFU} / \mathrm{mL}\right)$. E. coli $\mathrm{GFP}$ were non-specifically captured at $10^{2.3} \mathrm{CFU} / \mathrm{mL}$ with $1 \mu \mathrm{g} / \mathrm{mL}$ of NA passively adsorbed on an ELISA plate 
without $\mathrm{Ab}$ (Table 1). The log difference between the specifically and non-specifically captured bacteria was 2.6 for NA employed to capture biotinylated Ab-bacteria complexes (PI method) versus 1.2 with the AB method.

\subsection{Capture of E. coli with biotinylated aptamers and neutravidin}

Neutravidin was also used to capture biotinylated Apt either before bacterial capture (AB method) or as aptamer-bacteria complexes (PI method). The AB method did not show an increase over non-specific binding with NA (Table 1). With the PI method, E. coli GFP were captured at $10^{5.2} \mathrm{CFU} / \mathrm{mL}$, versus $10^{3.3} \mathrm{CFU} / \mathrm{mL}$ observed for non-specifically captured bacteria with NA and without added aptamer.

\subsection{Increasing capture efficiency with centrifugation}

It is assumed that bacterial capture on surfaces is hindered by electrostatic or other repulsive forces. Several strategies have been proposed to overcome this repulsion and improve contact with the surface such as centrifugation, electrophoresis and chemotaxis. We attempted to improve capture by centrifuging bacteria onto the surface. With the addition of centrifugation at $250 \mathrm{G}$ for $5 \mathrm{~min}, 10^{7.0} \mathrm{CFU} / \mathrm{mL}$ E. coli $\mathrm{GFP}$ were captured from suspensions containing $10^{8.2} \mathrm{CFU} / \mathrm{mL}$ compared to $10^{4.3} \mathrm{CFU} / \mathrm{mL}$ captured without centrifugation (Table 3). When centrifugation was performed at $550 \mathrm{G}$ for $10 \mathrm{~min}, 10^{7.1}$ $\mathrm{CFU} / \mathrm{mL}$ of $E$. coli GFP were captured. However, centrifugation also gave rise to higher amounts of non-specifically captured bacteria (on surfaces without $\mathrm{Ab}$ added) at $10^{4.1}$ $\mathrm{CFU} / \mathrm{mL}$ with centrifugation at 250 and $550 \mathrm{G}$ (Table 3). 
When capture was attempted on surfaces with passively absorbed goat Ab, without centrifugation, bacteria were captured at $10^{4.3}$ and $10^{3.4} \mathrm{CFU} / \mathrm{mL}$ from $10^{8.2}$ and $10^{7.2}$ $\mathrm{CFU} / \mathrm{mL}$ suspensions, respectively, but no bacteria were captured from a $10^{6.2} \mathrm{CFU} / \mathrm{mL}$ suspension. When centrifugation was employed at $250 \mathrm{G}$, bacteria were captured from suspensions containing $10^{8.2} \mathrm{CFU} / \mathrm{mL}\left(10^{7.0} \mathrm{CFU} / \mathrm{mL}\right), 10^{7.2} \mathrm{CFU} / \mathrm{mL}\left(10^{6.0} \mathrm{CFU} / \mathrm{mL}\right)$ and $10^{6.2} \mathrm{CFU} / \mathrm{mL}\left(10^{4.1} \mathrm{CFU} / \mathrm{mL}\right)$, and it also allowed detection down to $10^{5.2} \mathrm{CFU} / \mathrm{mL}$ $\left(10^{2.2} \mathrm{CFU} / \mathrm{mL}\right)($ Table 3$)$. Similar results were observed with centrifugation at $550 \mathrm{G}$.

Table 3: Use of centrifugation to enhance capture of $E$. coli GFP on ELISA plates without $\mathrm{Ab}$ and with passively absorbed goat $\mathrm{Ab}$.

\begin{tabular}{|c|c|c|c|c|}
\hline \multirow[t]{2}{*}{ Centrifugation* } & \multirow{3}{*}{$\begin{array}{c}\text { Log Bact. } \\
\text { Conc. } \\
(\mathrm{CFU} / \mathrm{mL})\end{array}$} & \multicolumn{2}{|c|}{ Captured bacteria } & \multirow{3}{*}{$\begin{array}{c}\text { Bacteria } \\
\text { Net Capture } \\
\log \left(\mathrm{C}_{\mathrm{Ab}} / \mathrm{C}_{\mathrm{nAb}}\right)\end{array}$} \\
\hline & & With Ab & Without Ab & \\
\hline & & $\log C(\mathrm{CFU} / \mathrm{mL})$ & $\log C(\mathrm{CFU} / \mathrm{mL})$ & \\
\hline \multirow{4}{*}{ No } & 8.2 & $4.3 \pm 0.8$ & $0.1 \pm 0.1$ & 4.2 \\
\hline & 7.2 & 3.4 & 0 & 3.4 \\
\hline & 6.2 & 0 & 0 & 0 \\
\hline & 8.2 & $7.0 \pm 0.5$ & $4.1 \pm 0.7$ & 2.9 \\
\hline \multirow{2}{*}{$250 \mathrm{G}$} & 7.2 & $6.0 \pm 0.1$ & & \\
\hline & 6.2 & $4.1 \pm 0.3$ & & \\
\hline \multirow{2}{*}{$5 \min$} & 5.2 & $2.2 \pm 0.4$ & 1.5 & 0.7 \\
\hline & 4.2 & 0 & & \\
\hline $550 \mathrm{G}$ & 8.2 & $7.1 \pm 1.0$ & $4.1 \pm 0.1$ & 3.0 \\
\hline
\end{tabular}




\begin{tabular}{lcccc}
\hline $10 \min$ & 7.2 & 6.5 & & \\
& 6.2 & 4.8 & 0.2 & 2.0 \\
5.2 & $2.2 \pm 1.0$ & & \\
\hline & 0.2 & 0 & & \\
\hline
\end{tabular}

* Bacteria at different concentrations were added to wells with or without passively adsorbed goat anti-E. coli Ab using $20 \mu \mathrm{g} / \mathrm{mL}$ of Ab. The plates were centrifuged at 250 $\mathrm{G}$ for $5 \mathrm{~min}$ or $550 \mathrm{G}$ for $10 \mathrm{~min}$, or not centrifuged, followed by $1 \mathrm{~h}$ incubation at $37^{\circ} \mathrm{C}$, and then bacteria titrated from the growth curves.

\subsection{Inhibition of bacterial growth by antibodies}

Tests showed that there was minimal $\left(10^{2.2} \mathrm{CFU} / \mathrm{mL}\right)$ bacterial capture when $10^{5.2}$

$\mathrm{CFU} / \mathrm{mL}$ or fewer bacteria were added to wells for capture with centrifugation, and none when fewer than $10^{7.2} \mathrm{CFU} / \mathrm{mL}$ were added without centrifugation. In order to determine whether Ab could have contributed to this lower capture efficiency by inhibiting bacterial growth, different concentrations of bacteria were added to wells with different concentrations of $\mathrm{Ab}$. Figure 2 demonstrates the effect of growth inhibition of bacteria by the increasing amount of $\mathrm{Ab}$. Suppression of bacterial growth was much more evident with 25 and $50 \mu \mathrm{g} / \mathrm{mL}$ than with $10 \mu \mathrm{g} / \mathrm{mL}$ or less of $\mathrm{Ab}$, and particularly for bacterial concentrations of $1.5 \times 10^{4}$ or less. 



Fig. 2: Comparison of time dependent fluorescence intensity from E. coli GFP bacterial dilutions between $1.5 \times 10$ and $1.5 \times 10^{6} \mathrm{CFU} / \mathrm{mL}$ grown in TG in microtitre plate wells without anti-E. coli $\mathrm{Ab}$, or in the presence of anti-E. coli $\mathrm{Ab}$ at $5 \mu \mathrm{g} / \mathrm{mL}$ (a) and 50 $\mu \mathrm{g} / \mathrm{mL}(\mathrm{b})$, and as a function of anti-E. coli $\mathrm{Ab}$ concentration after $6,8.5$ and $9.5 \mathrm{~h}$ of incubation (c).

\subsection{Bacterial degradation of antibodies and release from plates}

In Fig. 3, we compared the number of bacteria captured in uncoated wells of a microtitre plate and in wells coated with $\mathrm{Ab}$ at 100 and $20 \mu \mathrm{g} / \mathrm{mL}$. The number of bacteria that remained bound to those wells after up to $6 \mathrm{~h}$ of incubation in TG was measured 
following washing to remove released bacteria. A slightly greater concentration of bacteria was observed captured with $\mathrm{Ab}$ at $100 \mu \mathrm{g} / \mathrm{mL}$, compared with $\mathrm{Ab}$ at $20 \mu \mathrm{g} / \mathrm{mL}$, while a negligible number of bacteria was captured in wells without Ab. However, it can be seen that regardless of whether $\mathrm{Ab}$ at $20 \mu \mathrm{g} / \mathrm{mL}$ or $100 \mu \mathrm{g} / \mathrm{mL}$ had been employed, and despite washing, the number of retained bacteria increased with the incubation time, indicating capture of progeny rather than release due to Ab degradation. Clearly, under conditions of the current experiment, we could conclude that $E$. coli GFP did not degrade the $\mathrm{Ab}$ that captured it.

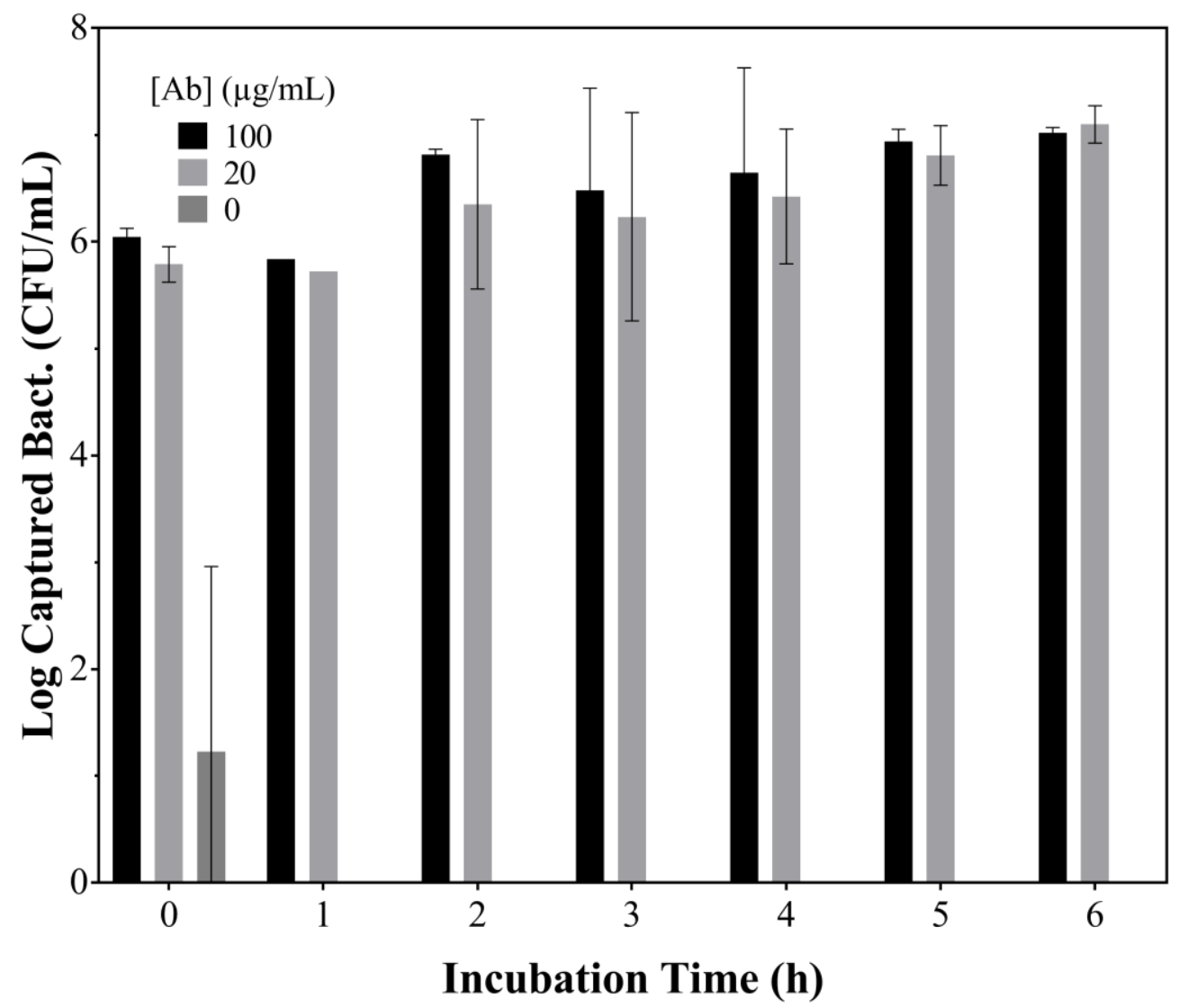

Fig. 3: Concentration of E. coli GFP bacteria captured in wells of a microtitre plate coated with $\mathrm{Ab}$ at 100 or $20 \mu \mathrm{g} / \mathrm{mL}$, washed, and then incubated at $37^{\circ} \mathrm{C}$ in $\mathrm{TG}$ for up to $6 \mathrm{~h}$, followed by washing to remove released bacteria. Note that the concentration of 
bacteria captured on the uncoated surface of a well was negligible in comparison to that of bacteria captured on Ab coated well surfaces.

\section{Discussion}

We have quantified bacteria capable of growing after capture on surfaces by measuring the doubling time necessary to reach the minimum number of bacteria required to produce detectable GFP fluorescence (Fig. 1). This method resembles the strategy used for the quantitative polymerase chain reaction (qPCR) where DNA copies double until they reach a minimal detectable amount called the quantification cycle threshold $(\mathrm{Ct})$. This is usually ascertained by identifying the first maximum value from the second derivative of the fluorescence curve $[38,39]$. Because this value may depend on amplification efficiency, it was proposed to identify the abscissa crossing point of the tangent of the inflection point of the Richard's curve obtained by non-linear regression of the raw fluorescence data [37]. In our quantification method with E. coli GFP, the bacteria also doubled each 20 to $30 \mathrm{~min}$ and the Tt can be determined by this method as well. As it can be seen in Fig. 1c, both the second derivative fluorescence data and data obtained from the abscissa crossing points provided a comparable dependence of $\mathrm{Tt}$ on bacterial concentration.

Our method is optimal for bacteria expressing fluorescent products like E. coli GFP, but methods based on optical density determination would be necessary for non-fluorescent bacteria. Interference with contaminating bacteria from the environment, however, could affect results, especially when few target bacteria are captured. When we followed $E$. coli growth with optical density at $600 \mathrm{~nm}$, our observed Tt were similar (data not shown). 
The qPCR technique could also be employed to quantify bacterial capture, but it would be more expensive and would probably not be able to quantify small numbers of bacteria captured as accurately as our procedure due to qPCR inherent lack of sensitivity with fewer than 10 bacteria [40-42] and with the requirement to use only part of the bacterial DNA extract from a well in small PCR reaction volumes.

Our procedure to quantify live $E$. coli based on growth is not as rapid as qPCR detection for low numbers of bacteria. Our experiments showed that the minimum concentration of live E. coli required for detection within 3 hours was at $10^{5.2} \mathrm{CFU} / \mathrm{mL}$ with single bacteria detection requiring as much as 9 hours (Fig. 1).

It was striking that the number of input bacteria able to grow after capture on an ELISA plate by a passively adsorbed goat $\mathrm{Ab}$ decreased precipitously from $10^{3.4}$ to 0 when the number of bacteria exposed to a surface decreased by only one order $\left(10^{7.2}\right.$ to $\left.10^{6.2}\right)$ (see Table 3 for data with no centrifugation). This implies that capture with growth does not proceed with one-hit kinetics, or alternatively, that growth is inhibited in a non-linear fashion. As results documenting capture and detection without growth have indicated linear relationships between number of bacteria captured and number presented $[7,35,43]$, it could be assumed that capture occurs by one-hit kinetics and probably implies that capture occurs when one $\mathrm{Ab}$ molecule interacts with one bacteria, and does not require several $\mathrm{Ab}$ with variable-binding energy to reach a total binding energy sufficient to oppose disruptive forces like electrostatic repulsion. Inhibition of growth must be suspected as the explanation for the rapid decline in growth potential after capture. Previously, we observed that the growth of E. coli on GaAs or Au surfaces required a minimum of $10^{5} \mathrm{CFU} / \mathrm{mL}$ [44], while testing the sensitivity of E. coli strains to 
antibiotics with a photoluminescence-based biosensor was not possible for bacterial concentrations under $2 \times 10^{8} \mathrm{CFU} / \mathrm{mL}$ [24]. It has been suggested that the toxic effects of Ga or As ions released by GaAs-based biochips might be the cause of this requirement for high bacterial concentration necessary to allow growth. In the experiments reported here, Ga and As were not present, and so inhibition may have resulted from the Ab used to capture the bacteria on the surface. Indeed, Ab added to cultures of bacteria inhibited bacterial growth dependant on the concentration of the $\mathrm{Ab}$ and the concentration of the bacteria. It might be possible to overcome this inhibition if it were possible to find an $\mathrm{Ab}$ that did not inhibit bacterial growth, but did capture the bacteria, in an analogous fashion to $\mathrm{Ab}$ that neutralize viruses versus $\mathrm{Ab}$ that react with viruses but do not neutralize them [45]. It is generally considered that antibodies classically inactivate bacteria in conjunction with complement or by opsonisation to enhance phagocytosis [46]. A few studies have shown direct antibody killing of bacteria by interaction with membrane bound enzymes [47, 48] or lipopolysaccharides [46, 49]. Chicken IgY antibodies have also been shown to directly kill E. coli. [50].

We employed centrifugation to overcome static repulsion between surfaces and bacteria and increase bacterial contact with $\mathrm{Ab}$. Centrifugation at low speed was used so as not to affect the bacterial surface [32]. Chemotaxis and electrophoresis have also been shown to improve capture of bacteria, e.g., E. coli and Legionella pneumophila by attracting them to glucose generated at the surface from lactose cleavage by surface-bound galactosidase enzyme [25]. Other authors have brought bacteria into contact with a surface by electrophoresis [51] or using alternating current electrokinetic effects [52]. These 
methods have been shown to improve the efficiency of capture and merit further study to improve and simplify them.

Purified $\operatorname{IgG}$ goat and $\operatorname{Ig} \mathrm{Y}$ chicken Ab bound passively to ELISA microplates gave similar crude growth/capture rates (Table 1 ). When goat $\mathrm{Ab}$ were bound covalently to microplates approximately $3-5$ times fewer bacteria grew after capture than when using passively bound $\mathrm{Ab}$. The lowest background values were observed with the EDC/NHS chemistry activated MHDA manufactured by Biacore. When NA was used to capture biotinylated $\mathrm{Ab}$ or Apt, it was found to bind $E$. coli resulting in high background levels for wells without $\mathrm{Ab}$ as has been reported previously [53]. Other bacteria may have less interaction with NA as it has been demonstrated previously for L. pneumophila [21] and Staphylococcus aureus [54]. Preincubating biotinylated Ab or Apt with bacteria and then adding to wells with NA already bound resulted in better crude rates of growth/capture than when bacteria were added to wells with biotinylated $\mathrm{Ab}$ or Apt already bound to the wells with passively adsorbed NA. However, even with preincubation, growth/capture was still not as efficient as with passively or covalently bound Ab.

The diversity of the capture molecules tested in this study was limited to polyclonal goat, polyclonal chicken $\mathrm{Ab}$ and $\mathrm{Apt}$, which act like monoclonal $\mathrm{Ab}$. It could be interesting to compare the capture efficiency between polyclonal and monoclonal Ab. Some studies have shown efficiency of polyclonal or monoclonal $\mathrm{Ab}$ and even compared different structures [7,8,55], but none has compared the efficiency of polyclonal vs monoclonal $\mathrm{Ab}$ with the same structure. The use of Apt for capture and detection of bacteria has been demonstrated [32,56-58]. In this study, Apt from other studies were used for the capture of $E$. coli GFP, but the results showed only modest efficiency due to high background. 
Monitoring bacterial sensitivity to antibiotics requires that the bacteria be growing. The present study indicates that $\mathrm{Ab}$ used to capture bacteria might contribute to the high level of bacterial concentrations required for studying reactions to antibiotics. It might be possible to reduce the impact of $\mathrm{Ab}$ on bacterial growth by choosing monoclonal $\mathrm{Ab}$ that capture the bacteria by targeting epitopes that do not inhibit bacterial growth. Our study shows that $E$. coli K12 BW25113 didn't degrade the Ab used for capture - a feature potentially attractive for biosensors designed for investigating resistance of these and similar bacteria to antibiotics. Other types of bacteria, particularly Streptococcus, may be capable of specifically degrading $\mathrm{Ab}$ [59], or produce extracellular proteases that will degrade $\mathrm{Ab}$. In the absence of reducing agents, however, $\mathrm{Ab}$ are relatively resistant to other proteases [60].

\section{Conclusions}

As a proxy for a biosensor surface, we have employed a 96 well ELISA plate surface in order to study different structures for binding and growth of bacteria. In comparison with reference passively adsorbed goat $\mathrm{Ab}$, we have investigated passively adsorbed chicken $\mathrm{Ab}$, covalently linked goat $\mathrm{Ab}$ to a plate with a carboxyl group and biotinylated goat $\mathrm{Ab}$ or biotinylated aptamers with passively adsorbed NA. With the GFP $E$.

coli K12 BW25113, we found that passively bound goat or chicken Ab was a better approach for tethering bacteria and allowing growth than a covalent binding strategy. Our experiments showed that the minimum concentration of live E. coli required for detection

within 3 hours was at $10^{5.2} \mathrm{CFU} / \mathrm{mL}$. Only $10^{3.4} \mathrm{CFU} / \mathrm{mL}$ of bacteria was captured on an ELISA plate with passively captured goat Ab from the initial concentration of bacteria at 
$10^{7.2} \mathrm{CFU} / \mathrm{mL}$, which represented $\mathrm{a} \sim 10^{-4}$ fraction of the initial concentration.

Furthermore, no capture of bacteria was observed for the concentration reduced to $10^{6.2}$ $\mathrm{CFU} / \mathrm{mL}$. Adding a centrifugation step considerably increased the capture of bacteria, but it also increased the background contribution. The use of NA resulted in increased nonspecific interactions, but better absolute capture performance and could be investigated further. Inhibition of bacterial growth with $\mathrm{Ab}$ in the growth medium could translate into inhibition of growth when capturing bacteria on a surface. In presence of $\mathrm{Ab}$ at $10 \mu \mathrm{g} / \mathrm{mL}$, we observed a drastic decrease of bacterial growth in TG medium at $1.5 \times 10^{5} \mathrm{CFU} / \mathrm{mL}$ and at lower bacterial concentrations. The growth of bacteria was only minimally affected if exposed to $\mathrm{Ab}$ at less than $10 \mu \mathrm{g} / \mathrm{mL}$. It might be possible to overcome the $\mathrm{Ab}$ growth inhibition of bacteria, if it were possible to find an $\mathrm{Ab}$ analogous to those that are known to neutralize viruses versus $\mathrm{Ab}$ that react with viruses but do not neutralize them [45]. Of particular importance to the development of future Ab-based immunosensors of bacterial reactions to antibiotics is that we have not observed degradation of anti-E. coli K12 BW25113 Ab, even after 6 h of incubation.

\section{Acknowledgement}

This research was supported by the Canada Research Chair in Quantum Semiconductors Program (Grant No 950-220304), the Fonds de Recherche Nature et Technologie du Québec (FRQNT) team research project No 2015 - PR-184056, and the Natural Sciences and Engineering Research Council of Canada Strategic Project (Grant No 494057). 


\section{References}

[1] ESCMID, Antibiotic Armageddon in UK and Europe by 2025, 2015.

[2] K.E. Fleming-Dutra, A.L. Hersh, D.J. Shapiro, M. Bartoces, E.A. Enns, T.M. File, J.A. Finkelstein, J.S. Gerber, D.Y. Hyun, J.A. Linder, R. Lynfield, D.J. Margolis, L.S. May, D. Merenstein, J.P. Metlay, J.G. Newland, J.F. Piccirillo, R.M. Roberts, G. V. Sanchez, K.J. Suda, A. Thomas, T.M. Woo, R.M. Zetts, L.A. Hicks, Prevalence of Inappropriate Antibiotic Prescriptions Among US Ambulatory Care Visits, 2010-2011, Jama. 315 (2016) 1864. doi:10.1001/jama.2016.4151.

[3] C. Nathan, O. Cars, Antibiotic Resistance - Problems, Progress, and Prospects, The New England Journal of Medicine. (2014) 2012-2014. doi:10.1056/NEJMp1415160.

[4] S. Ishii, M.J. Sadowsky, Escherichia coli in the Environment: Implications for Water Quality and Human Health., Microbes and Environments / JSME. 23 (2008) 101-108. doi:10.1264/jsme2.23.101.

[5] M. Mellata, Human and avian extraintestinal pathogenic Escherichia coli: infections, zoonotic risks, and antibiotic resistance trends., Foodborne Pathogens and Disease. 10 (2013) 916-32. doi:10.1089/fpd.2013.1533.

[6] A. Sikora, M. Wójtowicz-Bobin, M. Kozioł-Montewka, A. Magryś, I. Gładysz, Prevalence of Legionella pneumophila in water distribution systems in hospitals and public buildings of the Lublin region of eastern Poland, Annals of Agricultural and Environmental Medicine. 22 (2015) 195-201. doi:10.5604/12321966.1152064. 
[7] M. Barreiros dos Santos, J.P. Agusil, B. Prieto-Simón, C. Sporer, V. Teixeira, J. Samitier, Highly sensitive detection of pathogen Escherichia coli O157: H7 by electrochemical impedance spectroscopy, Biosensors and Bioelectronics. 45 (2013) 174-180. doi:10.1016/j.bios.2013.01.009.

[8] H. Jayamohan, B. Gale, B. Minson, C. Lambert, N. Gordon, H. Sant, Highly Sensitive Bacteria Quantification Using Immunomagnetic Separation and Electrochemical Detection of Guanine-Labeled Secondary Beads, Sensors. 15 (2015) 12034-12052. doi:10.3390/s150512034.

[9] N. Singhal, M. Kumar, P.K. Kanaujia, J.S. Virdi, MALDI-TOF mass spectrometry: an emerging technology for microbial identification and diagnosis, Frontiers in Microbiology. 6 (2015) 1-16. doi:10.3389/fmicb.2015.00791.

[10] C.D. Doern, S.M. Butler-Wu, Emerging and Future Applications of MatrixAssisted Laser Desorption Ionization Time-of-Flight (MALDI-TOF) Mass Spectrometry in the Clinical Microbiology Laboratory, The Journal of Molecular Diagnostics. 18 (2016) 789-802. doi:10.1016/j.jmoldx.2016.07.007.

[11] L. Martz, Funding faster diagnostics, Biocentury Innovations. (2015).

[12] J.R. Mediavilla, A. Patrawalla, L. Chen, K.D. Chavda, B. Mathema, C. Vinnard, L.L. Dever, Colistin- and Carbapenem-Resistant Escherichia coli Harboring mcr-1 and bla NDM-5, Causing a Complicated Urinary Tract Infection in a Patient from the United States, mBio. 7 (2016) 5-8. doi:10.1128/mBio.01191-16.Editor.

[13] The White House Administration, National Action Plan for Combating AntibioticResistant Bacteria, 2015. https://www.whitehouse.gov/the-press- 
office/2015/03/27/fact-sheet-obama-administration-releases-national-action-plancombat-ant.

[14] O. Lazcka, F.J. Del Campo, F.X. Muñoz, Pathogen detection: A perspective of traditional methods and biosensors, Biosensors and Bioelectronics. 22 (2007) 1205-1217. doi:10.1016/j.bios.2006.06.036.

[15] Y. Wang, Z. Ye, C. Si, Y. Ying, Monitoring of Escherichia coli O157:H7 in food samples using lectin based surface plasmon resonance biosensor, Food Chemistry. 136 (2013) 1303-1308. doi:10.1016/j.foodchem.2012.09.069.

[16] M. Vinay, N. Franche, G. Grégori, J.R. Fantino, F. Pouillot, M. Ansaldi, Phagebased fluorescent biosensor prototypes to specifically detect enteric bacteria such as E. coli and Salmonella enterica Typhimurium, PLoS ONE. 10 (2015) 1-17. doi:10.1371/journal.pone.0131466.

[17] R.R. Hu, Z.Z. Yin, Y.B. Zeng, J. Zhang, H.Q. Liu, Y. Shao, S. Bin Ren, L. Li, A novel biosensor for Escherichia coli O157: H7 based on fluorescein-releasable biolabels, Biosensors and Bioelectronics. 78 (2016) 31-36. doi:10.1016/j.bios.2015.11.018.

[18] Y.-L. Chiang, C.-H. Lin, M.-Y. Yen, Y.-D. Su, S.-J. Chen, H.-F. Chen, Innovative antimicrobial susceptibility testing method using surface plasmon resonance., Biosensors \& Bioelectronics. 24 (2009) 1905-1910. doi:10.1016/j.bios.2008.09.020.

[19] V. Duplan, E. Frost, J.J. Dubowski, A photoluminescence-based quantum semiconductor biosensor for rapid in situ detection of Escherichia coli, Sensors 
and Actuators, B: Chemical. 160 (2011) 46-51. doi:10.1016/j.snb.2011.07.010.

[20] E. Nazemi, S. Aithal, W.M. Hassen, E.H. Frost, J.J. Dubowski, GaAs/AlGaAs heterostructure based photonic biosensor for rapid detection of Escherichia coli in phosphate buffered saline solution, Sensors and Actuators B: Chemical. 207 (2015) 556-562. doi:10.1016/j.snb.2014.10.111.

[21] M.R. Aziziyan, W.M. Hassen, D. Morris, E.H. Frost, J.J. Dubowski, Photonic biosensor based on photocorrosion of GaAs/AlGaAs quantum heterostructures for detection of Legionella pneumophila, Biointerphases. 11 (2016) 19301. doi:10.1116/1.4941983.

[22] J. Lee, J. Kim, S.R. Ahmed, H. Zhou, J.M. Kim, J. Lee, Plasmon-induced photoluminescence immunoassay for tuberculosis monitoring using goldnanoparticle-decorated graphene, ACS Applied Materials and Interfaces. 6 (2014) 21380-21388. doi:10.1021/am506389m.

[23] M.K. Patel, M.A. Ali, S. Krishnan, V.V. Agrawal, A.A. Al Kheraif, H. Fouad, Z.A. Ansari, S.G. Ansari, B.D. Malhotra, A Label-Free Photoluminescence Genosensor Using Nanostructured Magnesium Oxide for Cholera Detection, Scientific Reports. 5 (2015) 1-8. doi:10.1038/srep17384.

[24] E. Nazemi, W.M. Hassen, E.H. Frost, J.J. Dubowski, Monitoring growth and antibiotic susceptibility of Escherichia coli with photoluminescence of GaAs/AlGaAs quantum well microstructures, Biosensors and Bioelectronics. 93 (2017) 234-240. doi:10.1016/j.bios.2016.08.112.

[25] W.M. Hassen, H. Sanyal, M. Hammood, K. Moumanis, E.H. Frost, J.J. Dubowski, 
Chemotaxis for enhanced immobilization of Escherichia coli and Legionella pneumophila on biofunctionalized surfaces of GaAs, Biointerphases. 11 (2016) 21004. doi:10.1116/1.4947048.

[26] F. Mustafa, R.Y.A. Hassan, S. Andreescu, Multifunctional nanotechnologyenabled sensors for rapid capture and detection of pathogens, Sensors (Switzerland). 17 (2017). doi:10.3390/s17092121.

[27] W. Wu, S. Zhao, Y. Mao, Z. Fang, X. Lu, L. Zeng, A sensitive lateral flow biosensor for Escherichia coli O157: H7 detection based on aptamer mediated strand displacement amplification, Analytica Chimica Acta. 861 (2015) 62-68. doi:10.1016/j.aca.2014.12.041.

[28] Y. Li, R. Afrasiabi, F. Fathi, N. Wang, C. Xiang, R. Love, Z. She, H.B. Kraatz, Impedance based detection of pathogenic E. coli O157: H7 using a ferroceneantimicrobial peptide modified biosensor, Biosensors and Bioelectronics. 58 (2014) 193-199. doi:10.1016/j.bios.2014.02.045.

[29] N. Idil, M. Hedström, A. Denizli, B. Mattiasson, Whole cell based microcontact imprinted capacitive biosensor for the detection of Escherichia coli, Biosensors and Bioelectronics. 87 (2017) 807-815. doi:10.1016/j.bios.2016.08.096.

[30] R.M. Lequin, Enzyme Immunoassay (EIA)/Enzyme-Linked Immunosorbent Assay (ELISA), Clin Chem 51(12) (2005) 2415-2418.

[31] G. Czilwik, T. Messinger, O. Strohmeier, S. Wadle, F. von Stetten, N. Paust, G. Roth, R. Zengerle, P. Saarinen, J. Niittymäki, K. McAllister, O. Sheils, J. O’Leary, D. Mark, Rapid and fully automated bacterial pathogen detection on a centrifugal- 
microfluidic LabDisk using highly sensitive nested PCR with integrated sample preparation, Lab Chip. 15 (2015) 3749-3759. doi:10.1039/C5LC00591D.

[32] R.S. Pembrey, K.C. Marshall, R.P. Schneider, Cell Surface Analysis Techniques: What Do Cell Preparation Protocols Do to Cell Surface Properties?, Appl. Envir. Microbiol. 65 (1999) 2877-2894. http://aem.asm.org/content/65/7/2877.full.

[33] Y.S. Kim, M.Y. Song, J. Jurng, B.C. Kim, Isolation and characterization of DNA aptamers against Escherichia coli using a bacterial cell-systematic evolution of ligands by exponential enrichment approach, Analytical Biochemistry. 436 (2013) 22-28. doi:10.1016/j.ab.2013.01.014.

[34] J.G. Bruno, M.P. Carrillo, T. Phillips, C.J. Andrews, A novel screening method for competitive FRET-aptamers applied to E. coli assay development, Journal of Fluorescence. 20 (2010) 1211-1223. doi:10.1007/s10895-010-0670-9.

[35] K. Bekir, H. Barhoumi, M. Braiek, A. Chrouda, N. Zine, N. Abid, A. Maaref, A. Bakhrouf, H. Ben Ouada, N. Jaffrezic-Renault, H. Ben Mansour, Electrochemical impedance immunosensor for rapid detection of stressed pathogenic Staphylococcus aureus bacteria, Environmental Science and Pollution Research. 22 (2015) 15796-15803. doi:10.1007/s11356-015-4761-7.

[36] J. Tan, B.D. Lee, L. Polo-Parada, S. Sengupta, Kinetically limited differential centrifugation as an inexpensive and readily available alternative to centrifugal elutriation, BioTechniques. 53 (2012) 104-108. doi:10.2144/0000113853.

[37] M. Guescini, D. Sisti, M.B. Rocchi, L. Stocchi, V. Stocchi, A new real-time PCR method to overcome significant quantitative inaccuracy due to slight amplification 
inhibition, BMC Bioinformatics. 9 (2008) 326. doi:10.1186/1471-2105-9-326.

[38] V. Luu-The, N. Paquet, E. Calvo, J. Cumps, Improved real-time RT-PCR method for high-throughput measurements using second derivative calculation and double correction, BioTechniques. 38 (2005) 287-293. doi:10.2144/05382RR05.

[39] Applied Biosystems, Essentials of Real Time PCR About Sequence Detection Chemistries TaqMan Chemistry, ReVision. (2005) 1-8.

[40] M.-J. Zhang, B. Qiao, X.-B. Xu, J.-Z. Zhang, Development and application of a real-time polymerase chain reaction method for Campylobacter jejuni detection., World Journal of Gastroenterology : WJG. 19 (2013) 3090-5. doi:10.3748/wjg.v19.i20.3090.

[41] B.G. Botaro, C.S. Cortinhas, L.V. Março, J.F.G. Moreno, L.F.P. Silva, N.R. Benites, M.V. Santos, Detection and enumeration of Staphylococcus aureus from bovine milk samples by real-time polymerase chain reaction, Journal of Dairy Science. 96 (2013) 6955-6964. doi:10.3168/jds.2013-6559.

[42] D.R. Adams, W.R. Stensland, C.H. Wang, A.M.O. Connor, W. Darrell, K.M. Harmon, E.L. Strait, T.S. Frana, D.W. Trampel, T.S.F. A, Detection of Salmonella Enteritidis in Pooled Poultry Environmental Samples Using a Serotype-Specific Real-Time - Polymerase Chain Reaction Assay, America Association of Avian Pathologists. 57 (2013) 22-28.

[43] Ö. Torun, I. Hakki Boyaci, E. Temür, U. Tamer, Comparison of sensing strategies in SPR biosensor for rapid and sensitive enumeration of bacteria, Biosensors and Bioelectronics. 37 (2012) 53-60. doi:10.1016/j.bios.2012.04.034. 
[44] E. Nazemi, W.M. Hassen, E.H. Frost, J.J. Dubowski, Growth of Escherichia coli on the GaAs (001) surface, Talanta. 178 (2018) 69-77. doi:10.1016/j.talanta.2017.08.097.

[45] G.S. Tan, P.E. Leon, R.A. Albrecht, I. Margine, A. Hirsh, J. Bahl, F. Krammer, Broadly-Reactive Neutralizing and Non-neutralizing Antibodies Directed against the H7 Influenza Virus Hemagglutinin Reveal Divergent Mechanisms of Protection, PLoS Pathogens. 12 (2016) 1-21. doi:10.1371/journal.ppat.1005578.

[46] Xie X, McLean MD, Hall JC. Antibody-dependent cell-mediated cytotoxicity- and complement-dependent cytotoxicity-independent bactericidal activity of an IgG against Pseudomonas aeruginosa O6ad. J Immunol. 184 (2010) 3725-33. doi: 10.4049/jimmunol.0902732.

[47] Storek KM, Auerbach MR, Shi H, Garcia NK, Sun D, Nickerson NN, Vij R, Lin Z, Chiang N, Schneider K, Wecksler AT, Skippington E, Nakamura G, Seshasayee D, Koerber JT, Payandeh J, Smith PA, Rutherford ST. Monoclonal antibody targeting the $\beta$-barrel assembly machine of Escherichia coli is bactericidal. Proc Natl Acad Sci U S A. 115 (2018) 3692-3697. doi: 10.1073/pnas.1800043115.

[48] Cabral MP, García P, Beceiro A, Rumbo C, Pérez A, Moscoso M, Bou G. Design of live attenuated bacterial vaccines based on D-glutamate auxotrophy. Nat Commun. 26 (2017) 15480. doi: 10.1038/ncomms15480.

[49] Apicella MA, Westerink MA, Morse SA, Schneider H, Rice PA, Griffiss JM. Bactericidal antibody response of normal human serum to the lipooligosaccharide of Neisseria gonorrhoeae. J Infect Dis. 153 (1986) 520-6. 
[50] Sunwoo HH, Lee EN, Gujral N, Suresh MR. Growth Inhibition of Escherichia coli 987P by Neutralizing IgY Antibodies. The Open Immunology Journal, 3 (2010) 18. doi: 10.2174/1874226201003010001]

[51] A.K. Balasubramanian, K.A. Soni, A. Beskok, S.D. Pillai, A microfluidic device for continuous capture and concentration of microorganisms from potable water, Lab on a Chip. 7 (2007) 1315-1321. doi:10.1039/B706559K.

[52] D.S. Liao, J. Raveendran, S. Golchi, A. Docoslis, Fast and sensitive detection of bacteria from a water droplet by means of electric field effects and micro-Raman spectroscopy, Sensing and Bio-Sensing Research. 6 (2015) 59-66. doi:10.1016/j.sbsr.2015.09.005.

[53] N. V. Kulagina, M.E. Lassman, F.S. Ligler, C.R. Taitt, Antimicrobial peptides for detection of bacteria in biosensor assays, Analytical Chemistry. 77 (2005) 65046508. doi:10.1021/ac050639r.

[54] A. Abbaspour, F. Norouz-Sarvestani, A. Noori, N. Soltani, Aptamer-conjugated silver nanoparticles for electrochemical dual-aptamer-based sandwich detection of staphylococcus aureus, Biosensors and Bioelectronics. 68 (2015) 149-155. doi:10.1016/j.bios.2014.12.040.

[55] Z. Shen, N. Hou, M. Jin, Z. Qiu, J. Wang, B. Zhang, X. Wang, J. Wang, D. Zhou, J. Li, A novel enzyme-linked immunosorbent assay for detection of Escherichia coli O157:H7 using immunomagnetic and beacon gold nanoparticles, Gut Pathogens. 6 (2014) 14. doi:10.1186/1757-4749-6-14.

[56] J. Bruno, Application of DNA Aptamers and Quantum Dots to Lateral Flow Test 
Strips for Detection of Foodborne Pathogens with Improved Sensitivity versus Colloidal Gold, Pathogens. 3 (2014) 341-355. doi:10.3390/pathogens3020341.

[57] R.B. Queirós, N. De-Los-Santos-Álvarez, J.P. Noronha, M.G.F. Sales, A label-free DNA aptamer-based impedance biosensor for the detection of E. coli outer membrane proteins, Sensors and Actuators, B: Chemical. 181 (2013) 766-772. doi:10.1016/j.snb.2013.01.062.

[58] W. Wu, J. Zhang, M. Zheng, Y. Zhong, J. Yang, Y. Zhao, W. Wu, W. Ye, J. Wen, Q. Wang, J. Lu, An Aptamer-Based Biosensor for Colorimetric Detection of Escherichia coli O157:H7, PLoS ONE. 7 (2012).

doi:10.1371/journal.pone.0048999.

[59] U. Von Pawel-Rammingen, L. Björck, IdeS and SpeB: Immunoglobulin-degrading cysteine proteinases of Streptococcus pyogenes, Current Opinion in Microbiology. 6 (2003) 50-55. doi:10.1016/S1369-5274(03)00003-1.

[60] B.J. Underdown, K.J. Dorrington, Studies on the structural and conformational basis for the relative resistance of serum and secretory immunoglobulin A to proteolysis, The Journal of Immunology. 112 (1974) 949-959. 


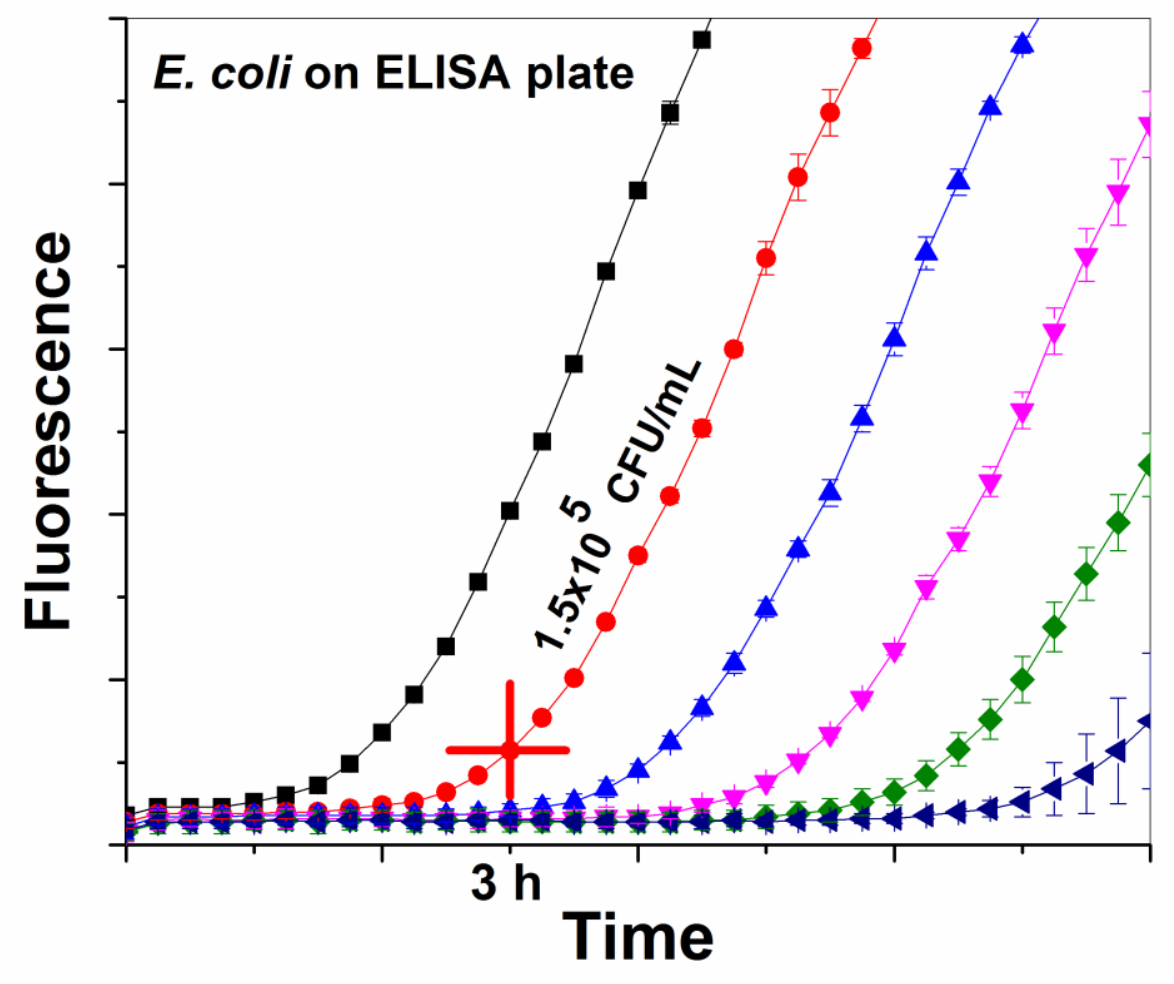

Graphical Abstract

\section{Highlights}

- Capture and growth inhibition of E. coli investigated on GaAs substrates

- Neutravidin (NA) binds E. coli nonspecifically

- Antibody binding to the surface of $E$. coli inhibits growth

- Minimum bacterial concentration determined by the antibody inhibition effect

- GaAs dark corrosion negligible in comparison to the antibody inhibition effect

- No degradation of anti-E. coli antibodies observed up to $6 \mathrm{~h}$ of incubation 